\title{
Study of the VAPEX Process in Fractured Physical Systems Using Different Solvent Mixtures
}

\author{
R. Azin ${ }^{1,2^{*}}$, R. Kharrat ${ }^{3}$, S. Vossoughi ${ }^{4}$ and C. Ghotbi ${ }^{1}$ \\ 1 Department of Chemical and Petroleum Engineering, Sharif University of Technology, Tehran - Iran \\ 2 Department of Chemical Engineering, School of Engineering, Persian Gulf University, Bushehr 75169 - Iran \\ 3 Petroleum University of Technology Research Center, Tehran - ran \\ 4 Department of Chemical and Petroleum Engineering, Kansas University, Lawrence, KS - USA \\ e-mail: reza.azin@pgu.ac.ir -kharra@@ut.ac.ir - shapour@ku.edu - ghotbi@sharif.ir
}

* Corresponding author

\begin{abstract}
Résumé - Étude du processus de VAPEX dans les systèmes physiques fracturés utilisant différents mélanges de solvants - Dans ce travail, le processus de l'extraction de la vapeur (VAPEX) est étudié expérimentalement dans un modèle rectangulaire physique à pression modérée et élevée. Le solvant a été soit du propane pur soit un mélange de propane et de méthane en différentes proportions. Le solvant et le gaz porteurs ont été mélangés totalement pendant les essais avant injection de sorte que le solvant avec la composition désirée a circulé à travers l'injecteur. Par ailleurs, le mélange du solvant était en équilibre thermodynamique avant d'être injecté dans la cellule de VAPEX. Les effets de la pression et la composition du solvant sont étudiés et les résultats montrent que le processus à pression fixe est plus efficace avec le solvant pur qu'avec les mélanges de solvants. La principale caractéristique de ce travail est que la récupération du pétrole lourd est améliorée lorsque la pression d'approche, définie comme la pression de saturation moins la pression d'opération, est réduite indépendamment de la composition du solvant ou de la pression d'opération. Ces résultats éclairent l'implémentation du processus de VAPEX dans un champ réel.
\end{abstract}

\footnotetext{
Abstract - Study of the VAPEX Process in Fractured Physical Systems Using Different Solvent Mixtures - In this work, the vapour extraction (VAPEX) process is studied experimentally in a rectangular physical model at moderate-high pressure. The solvent was either pure propane or a mixture of propane/methane with different compositions. The solvent and carrier gas were totally mixed before injection, so that a solvent with the desired composition flowed through the injector during experiments, and the solvent mixture was in thermodynamic equilibrium before injection into VAPEX cell. Effects of pressure and composition of solvent were studied. Results showed that at a fixed pressure, the process is more effective with pure solvent compared to the use of solvent mixtures. The main feature of this work is that heavy oil recovery is improved as the approach pressure, defined as the (saturation) pressure minus operating pressure, decreases regardless of solvent composition or operating pressure. These results provide insight into proper field scale implementation of the VAPEX process.
} 


\section{NOMENCLATURE}

\author{
$\Delta P_{\text {app }}$ Approach pressure, psi \\ $P_{\text {dew }} \quad$ Dew-point pressure, psi \\ $P^{\text {sat }} \quad$ Saturation pressure, $\mathrm{psi}$ \\ $P_{\text {op }} \quad$ Operating pressure, psi \\ $T \quad$ Temperature, ${ }^{\circ} \mathrm{C}$ \\ $\mu \quad$ Viscosity, Pa.s
}

\section{INTRODUCTION}

With the increasing world-wide demand for fossil energy sources, the heavy oil, extra heavy oil and natural bitumen reserves has become more attractive to be exploited. These huge resources estimated to be 4800 billion barrels (Gbbl) in place [1] are an important energy source for the next decades. The relatively high viscosity of heavy oil compared to conventional crude oil resources makes it difficult to be produced out of reservoir. Thermal processes like SteamAssisted Gravity Drainage (SAGD) and Cyclic Steam Stimulation (CSS) have been applied to some extent in heavy oil fields; however, it is questionable whether these methods are sufficient and economical in reservoirs with low porosity, low thermal conductivity, low thickness, and/or high fractures and fissures [2-3]. Furthermore, these processes are not environment friendly in terms of emissions and water consumption. For example, typical values of steam to oil ratio (SOR) for dry SAGD and CSS processes is between 2.5-3 and 3-4, respectively [4-5]. On the other hand, the Vapor Extraction (VAPEX) process, proposed by Butler and Mokrys $[4,5]$ as an alternative to SAGD process, is shown to be more attractive for thin reservoirs in which the heat losses to the under burden and overburden make thermal processes like SAGD process uncertain from economical point of view. The VAPEX process has been studied in conventional, nonfractured porous media using either pure solvents or solvents carried by a carrier gas [6-8]. Because of the relatively low vapor pressure of the pure low-molecular weight hydrocarbons normally applied as solvent, and considering the criteria of injecting the solvent at or near to its saturation conditions $[4,5]$, the use of pure solvents in VAPEX process is limited to certain reservoirs with low pressure. Due to this, previous experimental works were mostly conducted at low pressure conditions using pure solvents. The maximum pressure at which a pure solvent can be injected is limited to its critical pressure, which is corresponding to the solvent's critical temperature. Normally, for a certain reservoir, the temperature and pressure are known and remain unchanged until there is some oil withdrawn out of reservoir. Therefore, a reservoir engineer needs to add a non-condensable, carrier gas to the main solvent and design a solvent mixture with proper composition to match the reservoir conditions. In previous works $[7,8]$, a stream of gas carries a stream of liquid solvent; the liquid solvent is suspect to flow as a stream through carrier gas without mixing previously with it. In this case, any disturbance in pressure may cause the carrier gas to bypass the solvent flow. So, there can be potentially a risk of interruption in the solvent injection into reservoir. More over, there is a doubt about a solvent mixture with fixed composition is injected into heavy oil system; rather, a mixture suspect to changing composition flows through injector well.

Previous theoretical and experimental studies on the fractured system [9-12] showed that in the fractured system, due to differences in matrix and fracture permeabilities, the solvent first spreads through the fractures and then starts diffusing into the matrix and the cross flow enhances in the system. Thus, the solvent surrounds the oil bank and an oil chamber, rather than the solvent chamber is formed and shrinks as the process proceeds. Even for the side fractures being far apart from the bottom fracture, the solvent distribution differs significantly from that of the model with no fracture. When the matrix is surrounded by four connected fractures, combination of diffusion phenomenon and gravity segregation was observed to be the affecting mechanism of the VAPEX process in all the systems studied [9-12]. Also, increase of fracture-matrix contact directly improves the solvent-heavy oil contacts and results in higher oil recovery by VAPEX process, as the fractures are likely to enhance the VAPEX process by increasing the overall vertical permeability in the system, improving counter current flow of solvent and heavy oil, and providing more area for solvent diffusion. In this work, the experiments of VAPEX process with pure solvent in a fractured physical system $[9,12]$ are extended to the use of different solvent mixtures prepared by mixing propane (main solvent) and methane (carrier gas) with different proportions. The main feature of our work is that the solvent and carrier gas are completely mixed before injection, so that a solvent with the desired composition flows through the injector during experiments, and the solvent mixture is in thermodynamic equilibrium before injection into VAPEX cell. The experimental setup used in previous experiments was modified to meet this requirement. The paper is organized as follows. First, experimental setup and procedure is described. Then results are presented and effects of pressure and solvent composition on the process are discussed followed by conclusions.

\section{EXPERIMENTAL SETUP AND PROCEDURE}

Schematic of the experimental setup is shown in Figure 1. The main parts of experimental setup used in this work include a high-pressure cell, an air bath, a mass flow controller, a wet test meter, a back pressure regulator, an oil separator, and solvent cylinders. The high-pressure VAPEX cell was made of stainless steel 316 in rectangular form. Two metallic caps with $25 \mathrm{~mm}$ in thickness, made also of stainless 
steel 316 were used to cover the top and bottom of the cell. The internal dimensions of the cavity were $400 \mathrm{~mm}$ by $300 \mathrm{~mm}$ by $26 \mathrm{~mm}$. The top and bottom caps were fixed using 52 bolts for each side, with a plastic gasket in between. The model was tested up to 1600 psig $(11031 \mathrm{kPa})$ before experiments were started. Four fractures were made in the model by shaping the internal sides of the model and caps. Three fractures were connected, and used as the injectors. The fourth, bottom fracture was separated from the others and was used as the producer. The fractures were separated from the porous medium by stainless steel strips, which were perforated to make openings and welded together, with mesh-100 stainless steel screens in between in order to inhibit the sand to fill the fractures. In the case of conventional, non-fractured experiments, the strips are easily removed and the whole cavity is filled with either sand or glass bead.

Three valves were inserted at the top cap with $1 / 8$ " lines, and three valves were inserted in the bottom cap with $1 / 4$ " lines. A pressure gauge was fitted to one of the top valves. During experiments, the middle valves at the top and bottom were open and used for solvent injection and collection of the produced oil, respectively. The model was mounted on a metallic base with a gear that allowed rotating and positioning the model at different directions and angles. A mass flow meter (MFM) was used in the experiments for measuring and controlling flow rate of gases. The back pressure regulator (BPR) used in the experimental setup was a gas pressurized dome-type regulator, with a sensitive stainless steel diaphragm between the dome and the pressure controlled fluid.
To separate the produced oil and free gas at operation pressure, a high-pressure $500 \mathrm{cc}$ separator was used, which was made of stainless steel 316. It has three valves, two at the top and one in the bottom. One of the top valves is located right above the bottom valve, and is connected to the production line coming out of VAPEX cell. The other top valve is connected to the back pressure regulator in order to conduct free gas out of system. Also, it is used to pressurize the separator with an inert gas after draining oil. The bottom valve is used to drain the produced oil. Pure gas cylinders at mediumhigh pressure were used in the experiments. These gases include nitrogen $\left(\mathrm{N}_{2}\right)$, methane $\left(\mathrm{CH}_{4}\right)$, and propane $\left(\mathrm{C}_{3} \mathrm{H}_{8}\right)$ with purities at laboratory scale. Each cylinder was equipped with a proper regulator.

The oil used in the experiments was taken from Kuh-E-Mond heavy oil field located in the southwest part of Iran at the north of Persian Gulf Bank. Its API gravity was 12.8 at room temperature. The oil viscosity at room temperature was $58770 \mathrm{cp}$. When the viscosity data are fitted with the two-parameter Walther equation [13], the following correlation is obtained:

$$
\begin{aligned}
& \log _{10} \log _{10}(\mu+0.7) \\
& =12.12807-4.64094 \log _{10}(T+273.15)
\end{aligned}
$$

where $\mu$ is oil viscosity in centipoises and $T$ is temperature in ${ }^{\circ} \mathrm{C}$. Correlated oil viscosity versus experimental data for oil is shown in Figure 2. Equation 1 was obtained over the temperature and viscosity ranges of $15-70^{\circ} \mathrm{C}$ and $430-157180 \mathrm{cP}$, respectively. The average absolute deviation for viscosity estimation by this correlation is $3.68 \%$.

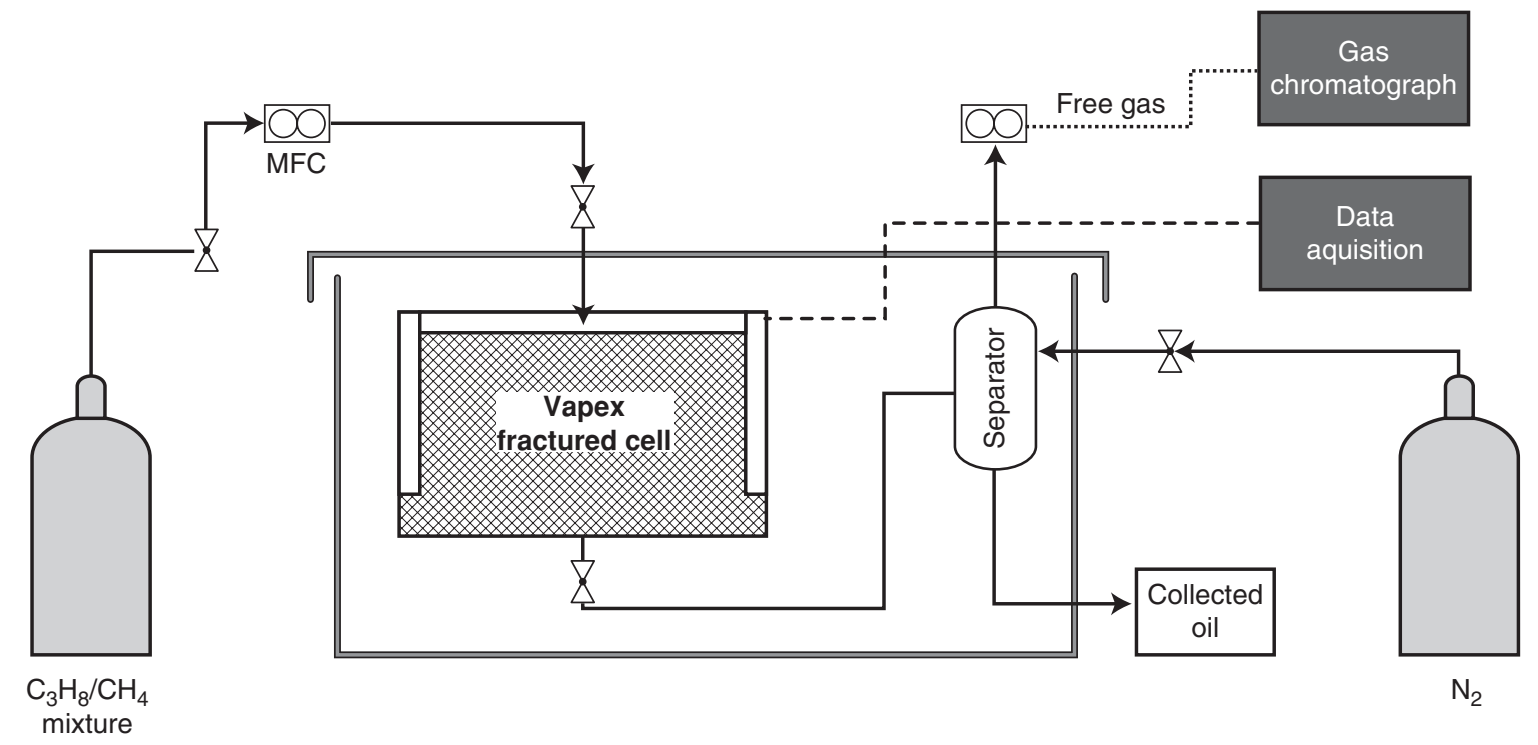

Figure 1

Schematic of experimental setup. 


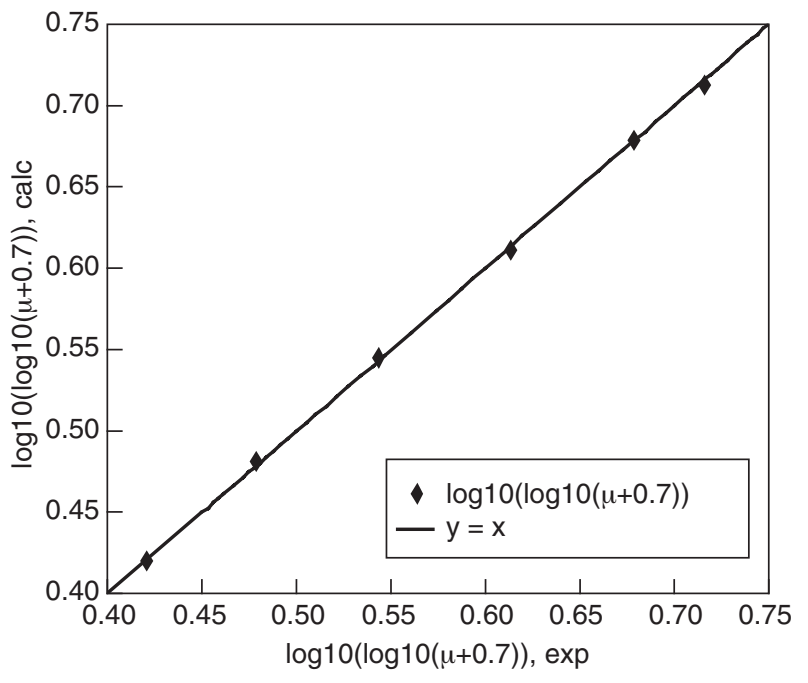

Figure 2

Correlated Heavy Oil viscosity versus experimental data.

TABLE 1

Properties of heavy oil used in this work [9]

\begin{tabular}{c|c}
\hline$P^{\text {sat }}(\mathrm{psia})$ & 624 \\
\hline Wax Content (wt\%) & 2.40 \\
\hline Asphaltene Content (wt $\%)$ & 24.1 \\
\hline Composition (mol\%) & \\
$\mathrm{N}_{2}$ & 0.66 \\
$\mathrm{CO}_{2}$ & 0.23 \\
$\mathrm{C}_{1}$ & 10.35 \\
$\mathrm{C}_{2}$ & 2.35 \\
$\mathrm{C}_{3}$ & 1.95 \\
$\mathrm{C}_{4}-\mathrm{C}_{5}$ & 11.5 \\
$\mathrm{C}_{6}-\mathrm{C}_{11}$ & 15.11 \\
$\mathrm{C}_{12+}$ & 57.86 \\
${\text { MW } \mathrm{C}_{12+}}$ & 485 \\
Sp.Gr. $\mathrm{C}_{12+}(60 / 60)$ & 1.0473 \\
\hline SARA Tests (wt $\%)$ & \\
Saturated & 21.83 \\
Aromatic & 53.59 \\
Resin & 9.58 \\
Asphaltene & 14.70 \\
\hline
\end{tabular}

Other properties of heavy oil are summarized in Table 1.

The solvent used in experiments was mixture of propane $\left(\mathrm{C}_{3} \mathrm{H}_{8}\right)$ and methane $\left(\mathrm{CH}_{4}\right)$ with different proportions. Also, pure methane $\left(\mathrm{CH}_{4}\right)$ was used to charge the oil separator located beneath the VAPEX cell to eliminate surges due to pressure differences during experiments. The solvent mixture was prepared by mixing the gases with the desired composition in a mixing cylinder, made of stainless steel 316 and designed to withstand medium to high pressures. The mixing cylinder was divided into two parts by a piston, so that the solvent mixture contained in one part can be pressurized by the application of water or gas pressure on the other part. The pressurized solvent mixture was then transferred into a high-pressure cylinder connected to the injection line. A stand-by cylinder was also charged with gas mixture to be replaced when the main cylinder is discharged and its pressure was just to fall below the operating pressure, thus ensuring that the process is continuous.

The VAPEX cell was packed with $1 \mathrm{~mm}$ glass beads, with a permeability of 830 Darcies and $39.5 \%$ porosity. The density of glass beads was measured and found to be $2.5 \mathrm{~g} / \mathrm{cc}$. Then, the oil was heated in the air bath to $70^{\circ} \mathrm{C}$, so that its viscosity was reduced to $200 \mathrm{cP}$ and became mobile. Next, the packed cell and fractures were saturated with oil. The top door was then closed and the cell was placed in the air bath by a hand crane. Finally, the inlet and outlet lines were connected to the system, and the whole setup was kept at constant temperature and atmospheric air bath for about 15 hours before starting the experiments. The system temperature was kept constant during the experiments in the air bath with precise temperature controller.

At the start of each experiment, the system was pressurized by vapour solvent to the desired pressure. Also, the oil trap located beneath the VAPEX cell was pressurized by nitrogen to the system pressure. The system pressure was adjusted by a back pressure regulator located at the exit vapour solvent/carrier gas line. The back pressure regulator was set to a pressure lower than the VAPEX cell pressure, in order to account for the pressure drops at the outlet equipment. During experiments, the produced oil accumulated in the oil trap was collected in separate bottles and weighed right after collection at suitable time intervals to obtain the rate and cumulative live oil production. During this, the production valve was closed. After collecting oil from oil trap at the end of each time interval, and before opening the production valve, the oil trap was charged by nitrogen up to the system pressure. Thus, any surge that can alter the experimental results was eliminated. At each time interval, the free gas flowing out the VAPEX cell was measured by collection in a bubbler via the displacement of water. The rate of free gas production is shown in Figure 3 for experiment with pure propane (experiment No. 4). At the end of each experiment, the VAPEX cell was blown down to atmospheric conditions to liberate the solvent remaining in the model.

\section{RESULTS AND DISCUSSION}

A total of four experiments were conducted. Three experiments were performed in the presence of solvent mixture, and the fourth run used pure propane. The experiment 


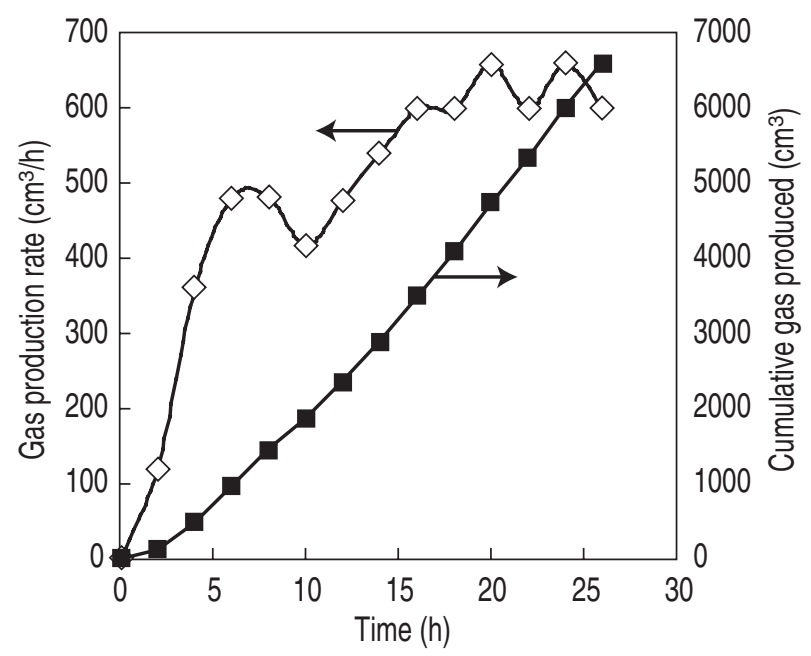

Figure 3

Gas production rate for experiment using pure solvent (114.7 psia).

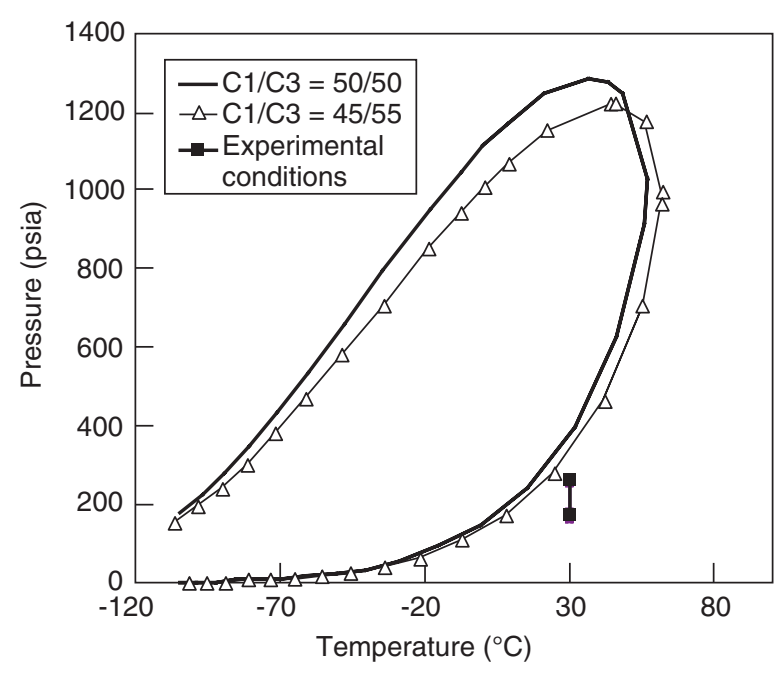

Figure 4

PT diagrams and operating conditions for the solvent mixture used in experiments.

TABLE 2

Summary of experimental conditions

\begin{tabular}{c|c|c|c|c|c|c|c|c|c}
\hline Exp. No. & Temp., ${ }^{\circ} \mathrm{C}$ & Press., $P$ sig & $\begin{array}{c}\text { Solvent }\left(\mathrm{C}_{3}\right) \\
\text { mole } \%\end{array}$ & $\begin{array}{c}\text { Solvent partial } \\
\text { pressure, } \mathrm{psia}\end{array}$ & $\begin{array}{c}\text { Carrier Gas } \\
\left(\mathrm{C}_{1}\right) \text { mole } \%\end{array}$ & $\begin{array}{c}\text { Oil Prod. } \\
\text { Rate, } \mathrm{g} / \mathrm{h}^{(1)}\end{array}$ & $\begin{array}{c}\text { Max. Oil Prod. } \\
\text { Rate, } \mathrm{g} / \mathrm{h}\end{array}$ & $\begin{array}{c}\text { Ultimate Oil } \\
\text { Recovery, } \%(2)\end{array}$ & \begin{tabular}{c} 
Notes \\
\hline 1
\end{tabular} \\
\hline 30 & 155 & 50 & 84.9 & 50 & 19.5 & 37.2 & 43.3 & $\mathrm{a}, \mathrm{b}, \mathrm{c}$ \\
2 & 30 & 240 & 50 & 127.4 & 50 & 28.5 & 60 & 54.6 & $\mathrm{~d}$ \\
3 & 30 & 155 & 55 & 93.3 & 45 & 26.8 & 46.6 & 49.6 & $\mathrm{e}$ \\
4 & 30 & 120 & 100 & 134.7 & 0 & 42.5 & 95.5 & 79.8 & \\
\hline
\end{tabular}

a. Ultimate oil recovery was obtained after 16.5 hours.

b. Operating pressure was reduced to $145 \mathrm{psig}$ after 24.5 hours.

c. The process was continued with just methane injection after 27 hours.

d. The Process was started at $300 \mathrm{psig}$, but it was reduced to $240 \mathrm{psig}$ after 2 hours in order to maintain the system pressure for a longer time.

e. The Process was started at $240 \mathrm{psig}$, but it was reduced to $155 \mathrm{psig}$ after 2.25 hours in order to maintain the system pressure for a longer time.

1 Average during the whole experiment.

2 These values were considered with overall production time.

conditions are summarized in Table 2. Two experiments were performed at the same pressure, but the composition of solvent injected into system was different. Also, in two experiments, the solvent composition was the same, but the operating pressure was changed. Figure 4 shows the pressure-temperature (PT) diagrams and position of operating conditions with respect to the dew-point curve of these runs.

In the first experiment, the process was started at $155 \mathrm{psig}$ and maintained at this pressure for 24.5 hours. After that, the system pressure was reduced to $145 \mathrm{psig}$ to examine possible extra heavy oil production at a lower pressure. This resulted in an extra heavy oil production until the pressure in the solvent mixture cylinder dropped, so that it could not supply solvent with the desired pressure. Then, after 2 hours operation at this pressure and before terminating the experiment, injection of solvent mixture was stopped and pure methane was injected into the system at 145 psig and without any pressure drop in the system to investigate possible oil production by injecting a non-condensable gas after injecting solvent for a long time. However, this did not give result to considerable oil production under gravity, i.e. without pressure gradient in the system. Figure 5 shows the results of this experiment at different intervals. As can be seen in this Figure, the process has little oil recovery after the solvent injection was stopped. 


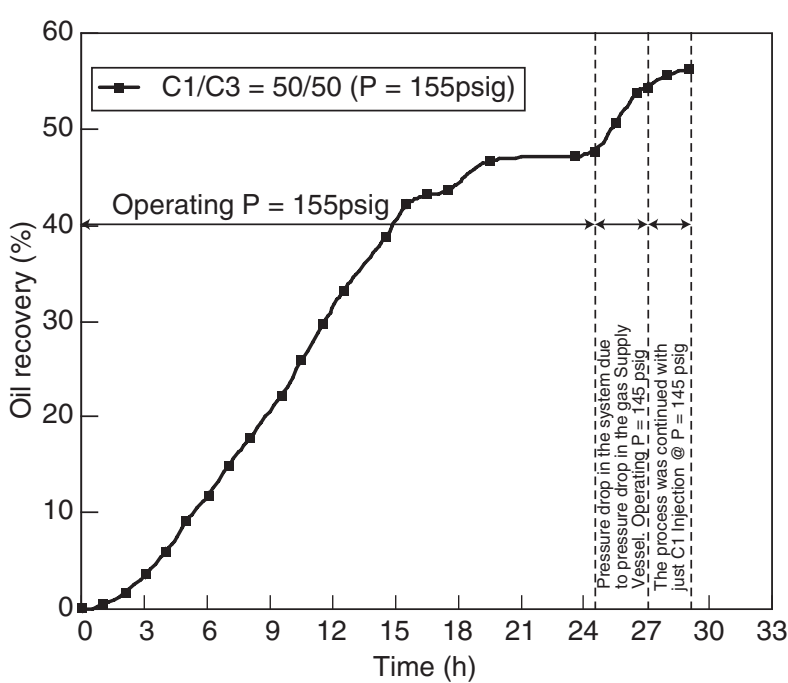

Figure 5

Oil recovery obtained in Experiment \#1.

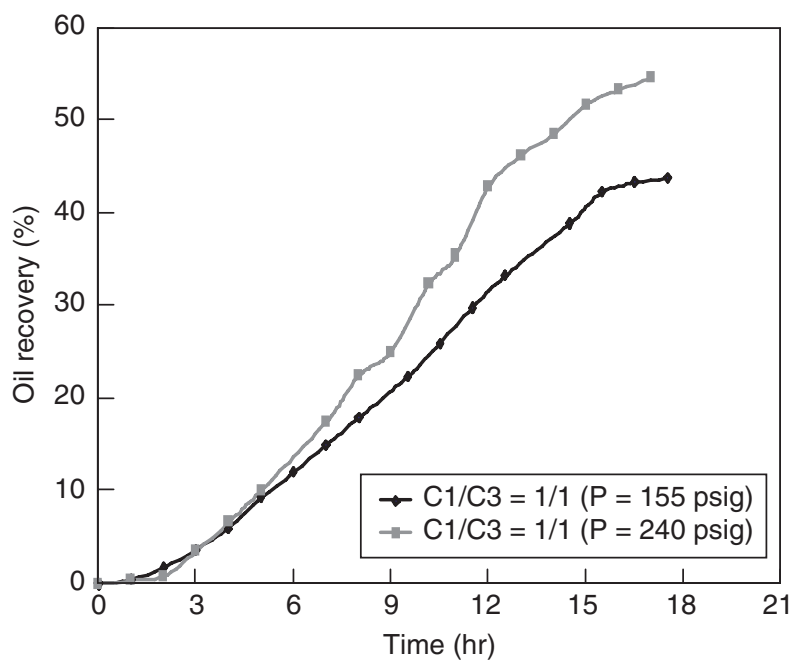

Figure 6

Effect of operating pressure on the oil recovery by VAPEX process.

\subsection{Effect of Pressure}

In experiment \#2, the same solvent as in the experiment \#1 was used at an operating pressure of $240 \mathrm{psig}$, which is closer to the dew-point curve. As shown in Figure 6, the early time oil production was close to the previous experiment. However, the oil recovery increased after 4 hours so that the ultimate oil production at the end of experiment was higher than that obtained in the experiment \#1. The higher partial pressure of main solvent (propane) at higher pressures accounts for higher oil recovery. Furthermore, when the pressure is increased, the solvent mixture approaches the dew-point curve as shown in Figure 4, which implies higher solubility of mixture in heavy oil and therefore higher oil recovery.

The operating pressure can overshadow the effect of solvent content of the mixture. Figure 7 compares the oil recovery in two experiments with different solvent composition and operating pressures. In one experiment, the solvent mixture and operating conditions were $C_{1} / C_{3}=50 / 50$ ( $\mathrm{mol} / \mathrm{mol}$ ) and $240 \mathrm{psig}$, respectively. In another experiment, the solvent mixture and operating conditions were $\mathrm{C}_{1} / \mathrm{C}_{3}=$ 45/55 and 155 psig, respectively. According to Figure 7, the system with higher pressure becomes more efficient and results in higher ultimate oil recovery. This is because of the higher partial pressure of propane in the system with higher pressure. The concentration of propane for each system is calculated based on its partial pressure and summarized in the column 5 of Table 2. As shown in Table 2, the partial pressure of propane for the so-called systems is 93.3 and 127.4 psia, respectively. Therefore, a system with higher

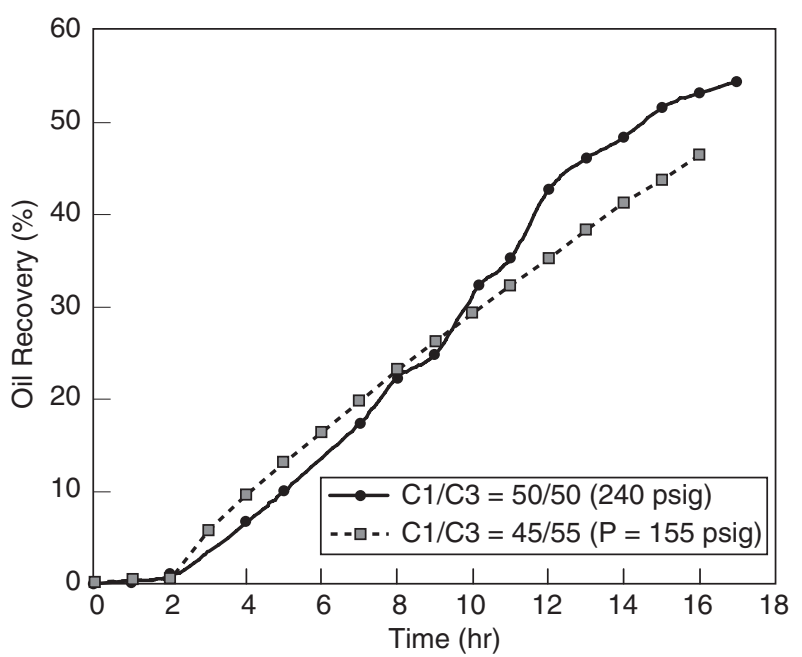

Figure 7

Comparison of heavy oil recovery at different solvent concentrations and injection pressures.

partial pressure of solvent gives better results, even if it has a lower solvent content. In other words, the partial pressure of the solvent in a solvent mixture, rather than its concentration, determines the efficiency of a certain solvent mixture in heavy oil recovery.

A closer look at the phase envelopes shown in Figure 4 indicates that the dew-point pressure at $30^{\circ} \mathrm{C}$ is $380 \mathrm{psia}$ and 340 psia for the systems with $\mathrm{C}_{1} / \mathrm{C}_{3}=50 / 50$ and $C_{1} / C_{3}=45 / 55$, respectively. Therefore, in the first 
experiment with $\mathrm{C}_{1} / \mathrm{C}_{3}=50 / 50$, the operating pressure ( 240 psig 255 psia) is $380-255=125$ psi lower than the dew-point pressure, whereas the second experiment with $\mathrm{C}_{1} / \mathrm{C}_{3}=45 / 55$ was operated at a (155 psig 170 psia) pressure, which is $340-170=170$ psi lower than the dew-point pressure. In other words, the first mixture is closer to the dew-point curve, which results in a higher solubility of solvent in heavy oil. Therefore, the overall heavy oil recovery is improved in the first experiment. The overall process efficiency increases with the decrease in the approach pressure, defined as the difference between saturation pressure and operating pressure:

$$
\Delta P_{\text {app. }}=P_{\text {dew }}\left(P^{\text {sat })}-P_{\text {op }}\right.
$$

where $\Delta P_{\text {app }}, P_{\text {dew }}, P^{\text {sat }}$, and $P_{\text {op }}$ are the approach pressure, the dew-point pressure, saturation pressure and operating Pressure, respectively.

A decrease in the approach pressure implies that operating conditions approach the saturation curve. As the solvent solubility increases near the saturation conditions, the decrease in the approach pressure makes more solvent dissolved in oil; eventually, this results in an improved oil recovery. The approach pressure for each experiment is calculated and summarized in Table 3 . When a pure solvent is injected, its saturation pressure is used to calculate the approach pressure; in the case of a solvent mixture, the dew-point pressure is used. Experimental results show that the systems with lower approach pressure give better results. However, it should be noted that decreasing the approach pressure should be made up to a minimum value below the saturation curve in order to avoid liquefaction of solvent. It was found that [9] when the solvent is injected very close to its saturation conditions, there is a risk of a sudden pressure drop in the lines and fittings that deliver solvent in the system. As a result, solvent liquefaction will occur, which results in the plugging and reduction of process efficiency.

\subsection{Effect of Solvent Composition}

As shown in Figure 4, the increase in the solvent content of injecting mixture changes the PT diagram. As a result, the operating condition of the process will be closer to the saturation conditions; in other words, increasing the solvent content decreases the approach pressure of experiments at preset pressures. Figure 8 shows results of another set of runs, where the composition of solvents was different but the operating pressure was the same (Experiments 1 and 3). Results reveal that higher solvent content of the injecting gas resulted in higher cumulative oil production. According to Figure 8, increasing the solvent (i.e. propane) content of injecting gas by $5 \%$ increases the oil recovery by about $5 \%$ in 17 hours. The increase in propane content of the solvent mixture causes the phase envelope of solvent mixture to change, so that the state of injecting gas at the same operating pressure is closer to the dew-point curve. Thus, the approach pressure decreases, and the oil recovery is higher, as was observed in these experiments.

Figure 9 compares heavy oil recovery using pure and mixture solvents. The ultimate recovery in the experiment with pure solvent is higher than all of mixture solvents. In other words, presence of carrier gas with a much less solubility than the main solvent in the solvent mixture slow the mass transfer between vapour (solvent mixture) and liquid (heavy oil). One of the reasons for this finding is that because of the lower partial pressure of solvent, the diffusivity of solvent through a mixture in the vapor phase is smaller than diffusivity of a pure solvent. Also, the solvent molecules need to diffuse through the mixture gas phase before diffusion into heavy oil. Another point that is inherent in this Figure is that as the operating pressure approaches the dew-point pressure, the oil recovery is improved. In other words, Figure 9 shows that heavy oil recovery is affected by approach pressure, rather than the operating pressure itself; heavy oil recovery is improved as the approach pressure decreases, regardless of

TABLE 3

Approach pressure for different solvent mixtures

\begin{tabular}{|c|c|c|c|c|c|c|c|}
\hline Exp. No. & Temp., ${ }^{\circ} \mathrm{C}$ & $\begin{array}{c}\text { Solvent }\left(\mathrm{C}_{3}\right) \\
\text { mole } \%\end{array}$ & $\begin{array}{l}\text { Dew Point }\left(P_{\text {dew }}\right) \\
\text { /Saturation }\left(P^{\mathrm{sat}}\right)^{(1)} \\
\text { pressure, psia }\end{array}$ & $\begin{array}{c}\text { Operating Pressure, } \\
\qquad P_{\mathrm{op}}, \text { psia }\end{array}$ & $\begin{array}{c}\text { Approach Pressure, } \\
\Delta P_{\text {app }}, \text { psia }\end{array}$ & $\begin{array}{l}\text { Ultimate Oil } \\
\text { Recovery, \% }\end{array}$ & Notes \\
\hline 1 & 30 & 50 & 380 & 170 & 210 & 43.3 & $\mathrm{a}$ \\
\hline 2 & 30 & 50 & 380 & 255 & 170 & 46.6 & $\mathrm{a}$ \\
\hline 3 & 30 & 55 & 340 & 170 & 125 & 54.6 & a \\
\hline 4 & 30 & 100 & 160 & 135 & 25 & 64.2 & $a, b$ \\
\hline
\end{tabular}

a. Ultimate oil recovery was obtained after 16.5 hours.

b. Pure solvent.

1 In the case of pure solvent, saturation pressure is used to calculate approach pressure. 


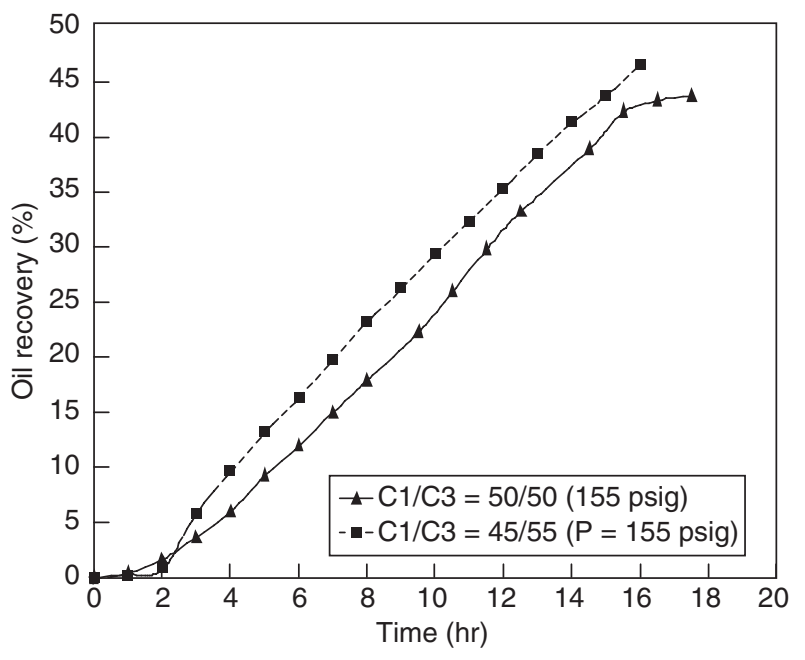

Figure 8

Effect of solvent concentration on the oil recovery by VAPEX process

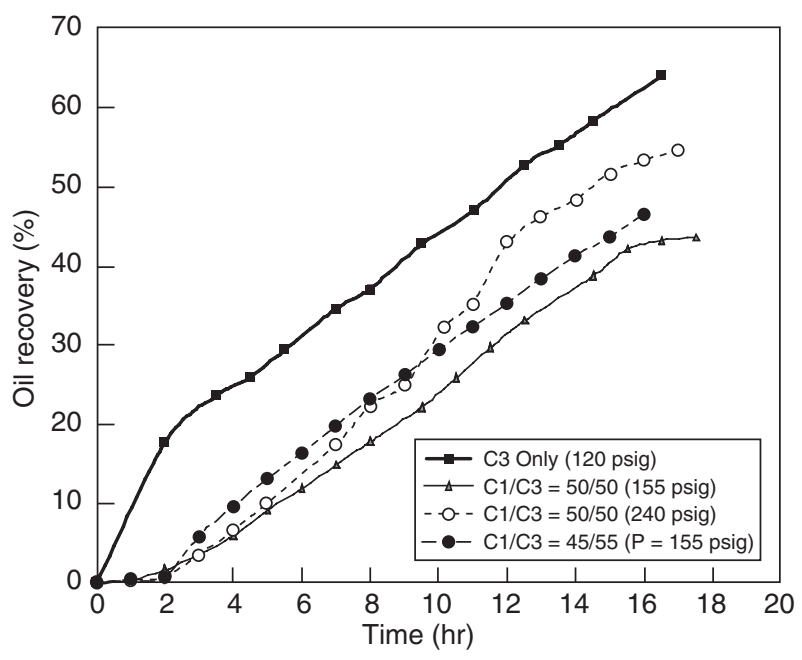

Figure 9

Comparison of heavy oil recovery using pure and mixture solvents. solvent composition or operating pressure. However, care is needed when the approach pressure is near zero, i.e. the solvent at or very close to its saturation pressure is injected into system, and the process is suspect to solvent liquefaction and plugging at these conditions.

\section{CONCLUSIONS}

Reported experimental studies of the VAPEX process in the literature are mainly at low pressure. In this paper, we presented experimental investigation of the vapour extraction (VAPEX) process in a rectangular physical model at moderate- high pressure. Effect of operating pressure on oil recovery was studied. In addition, we study the effect of solvent mixture composition on oil recovery. The oil recoveries of solvent mixtures at different operating pressure are compared with pure solvent injection. We found that at a fixed solvent composition, increasing operating pressure up to the dewpoint pressure results in a better oil recovery. It is also found that using solvent mixtures result in a lower oil recovery compared with using pure solvent. In addition, we found that oil recovery is improved as the approach pressure decreases, regardless of solvent composition or operating pressure. These results provide insight into appropriate field scale implementation of the VAPEX process.

\section{ACKNOWLEDGEMENTS}

The assistance of Mr. Salimi, the PUT technician in fulfilling the experiments is appreciated. The authors also appreciate
Dr. H. Hassanzadeh from University of Calgary for his valuable comments in preparing this paper.

\section{REFERENCES}

1 Saniere A., Hénaut I., Argillier J.F. (2004) Pipeline Transportation of Heavy Oils, A Strategic, Economic and Technological Challenge, Oil Gas Sci. Technol. 59, 5, 455466.

2 Singhal A.K., Das S.K., Leggitt S.M., Kasraie M., Ito Y. (1996) Screening of Reservoirs for Exploitation by Application of Steam Assisted Gravity Drainage / VAPEX Processes, SPE 37144, presented at the SPE international conference on horizontal well technology Proceedings, November 18-20, Calgary, Canada.

3 Talbi K., Maini B.B. (2003) Evaluation of $\mathrm{CO}_{2}$-based VAPEX Process for the Recovery of Bitumen from Tar Sand Reservoirs, SPE 84868, presented at the SPE International Improved Oil Recovery Conference in Asia Pacific, October 20-21, Kuala Lumpur, Malaysia.

4 Butler R.M., Mokrys I.J. (1989) Solvent analog model of Steam-Assisted Gravity Drainage, AOSTRA J.Res. 5, 1, 17.

5 Butler R.M., Mokrys I.J. (1991) A New Process (VAPEX) for Recovering Heavy oils Using Hot Water and Hydrocarbon Vapor, J. Can. Petrol. Technol. 30, 1, 97-106.

6 Das S.K., Butler R.M. (1998) Mechanism of Vapor Extraction Process for Heavy Oil and Bitumen, J. Petrol. Sci. Eng. 21, 1-2, 43-59.

7 Jiang Q. (1997) Recovery of Heavy Oil and Bitumen Using VAPEX Process in Homogeneous and Heterogeneous Reservoirs, Ph.D. Dissertation, the University of Calgary.

8 Butler R.M., Jiang Q. (2000) Improved Recovery of Heavy oil by VAPEX with widely spaced horizontal injectors and producers, J. Can. Petrol. Technol. 39, 1, 48-56.

9 Azin R. (2007) Investigation of the VAPEX Process in Fractured Reservoirs, Ph.D. Dissertation, Sharif Univ. Tech. 
10 Azin R., Kharrat R., Ghotbi C., Vossoughi Sh., Rostami B. (2007) Investigation of the VAPEX Performance in High Pressure Heavy Oil Reservoirs, IJCCE 25, 3, in press.

11 Azin R., Kharrat R., Rostami B., Vossoughi Sh. (2007) Simulation Study of the VAPEX Process in Fractured Heavy Oil System at Reservoir Conditions, J. Petrol. Sci. Eng. in press.
12 Azin R., Kharrat R., Ghotbi C., Vossoughi Sh. (2007) Improved Heavy Oil Recovery by VAPEX Process in the presence of Vertical and Horizontal Fractures, IJCCE, in press.

13 Mehrotra A.K., Monnery W.D., Svrcek W.Y. (1996) A Review of Practical Calculation Methods for the Viscosity of Liquid Hydrocarbons and Their Mixtures, Fluid Phase Equilibr. 117, 344-355.

Final manuscript received in September 2007

Copyright $(\odot 2007$ Institut français du pétrole

Permission to make digital or hard copies of part or all of this work for personal or classroom use is granted without fee provided that copies are not made or distributed for profit or commercial advantage and that copies bear this notice and the full citation on the first page. Copyrights for components of this work owned by others than IFP must be honored. Abstracting with credit is permitted. To copy otherwise, to republish, to post on servers, or to redistribute to lists, requires prior specific permission and/or a fee: Request permission from Documentation, Institut français du pétrole, fax. +33147527078 , or revueogst@ifp.fr. 